University of Nebraska - Lincoln

DigitalCommons@University of Nebraska - Lincoln

Agronomy \& Horticulture -- Faculty Publications

Agronomy and Horticulture Department

4-1946

\title{
Annual Increase of Underground Materials in Three Range Grasses
}

J. E. Weaver

University of Nebraska-Lincoln

Ellen Zink

Follow this and additional works at: https://digitalcommons.unl.edu/agronomyfacpub

Part of the Plant Sciences Commons

Weaver, J. E. and Zink, Ellen, "Annual Increase of Underground Materials in Three Range Grasses" (1946). Agronomy \& Horticulture -- Faculty Publications. 487.

https://digitalcommons.unl.edu/agronomyfacpub/487

This Article is brought to you for free and open access by the Agronomy and Horticulture Department at DigitalCommons@University of Nebraska - Lincoln. It has been accepted for inclusion in Agronomy \& Horticulture -Faculty Publications by an authorized administrator of DigitalCommons@University of Nebraska - Lincoln. 


\section{ANNUAL INCREASE OF UNDERGROUND MATERIALS IN THREE RANGE GRASSES ${ }^{1}$}

\section{J. E. Weaver and Ellen Zink}

\section{INTRODUCTION}

Any thoughtful student who has seen the mellow, granular, fiber-filled soil of virgin midwestern prairie and the same soil that has been cropped with maize or wheat for only a decade has cause for deep concern. For the cropped soil has lost its mellowness, the granular structure of discrete crumbs has largely disappeared as has also the binding root fiber. The soil when dry is often like dust, dust that pours between the fingers and is dispersed by the wind before it reaches the ground. Throughout the Midwest soil drifting has greatly increased, and erosion by water has become accelerated with length of time of cultivation and the cropping of more arid lands. Such soils have lost much of their fertility. They are greatly reduced in water-absorbing and waterholding capacity, and because of their small percentage of aggregates or their single-grain condition they may readily drift.

Grasses not only provide the soil with a protective cover against the forces of erosion but they also bring about a recovery of soil fertility which has been partly exhausted by continuous cropping. Under a cover of grass, a favorable crumb structure (the amount of which is a rough measure of the fertility of a given soil) is produced. These aggregates, a high percentage of which are large, are much more resistant to movement by wind and vater than are the particles of dust. They promote rapid absorption of water and permit freer movement of both water and gases within the soil. Soil aggregation under grassland as brought about biologically is partly through the accumula-

1 Contribution from the Department of Botany, University of Nebraska, No. 149. The investigation was aided by a grant to the senior author from the Graduate Council of the University of Nebraska. tion of rapidly decomposing organic matter, especially as it undergoes decay and is synthesized into humus. Much of this is from the roots that are widely and rather uniformly spread throughout. $\mathrm{Ag}$ gregation is partly through the mechanical effects of the fibrous root system holding the smaller aggregates together as well as the disruptive action of root penetration. Viscous microbial products may also play a part. The amounts and nature of soilbinding materials left by cereal crops are not sufficient to offset pulverization of soil in tillage operations. Perennial grasses are not only the most efficient natural producers of a granular soil structure, but also the erosion-resistant soil structure of soil aggregates and root fiber built up by them may last for several years after the sod is broken.

Man has slowly come to recognize that grass is his most efficient weapon against soil erosion; it is also an excellent preventive of soil depletion. Newell ('44) stated: "In recent years there has been a marked improvement . . . in the degree of appreciation of the importance of properly constructed crop and herbage rotations as the foundation of a permanent, stable, soil-conserving agriculture. The bases of such a soil-improving, soil-protecting rotation is the grass-legume sward of the temporary ley, or the forage crop of arable land. This has entailed a change in attitude towards grass of the American farm owner and farm worker; these are now realizing, as many are realizing in other parts of the world, that grass is a crop and requires to be farmed like a crop."

Just how much root material is produced annually by various perennial grasses, how many growing seasons are necessary for maximum production, and what is the rate of decay after the land is plowed, are fundamental questions in 
grass-legume and grain-crop rotations (alternate husbandry). To these questions a review of the literature gives almost no answers. Exceptions are information on brome grass, crested wheat grass, and slender wheat grass grown in an arid climate (Stevenson and White, '41 ; Pavlychenko, '42), and root production the first season of seven southern grasses (Burton, '43).

Studies by the writers on the rate of root decay of perennial grasses throughout the soil profile are nearing completion; the present paper deals with seasonal increase of roots of certain forage grasses.

\section{Methods}

Grasses used in this study were the most abundant dominants of tall-grass prairie and mid-grass or true prairie, respectively. They were big bluestem ( $A n$ dropogon furcatus Muhl.) and little bluestem (A. scoparius Michx.). Blue grama (Bouteloua gracilis (H.B.K.) Lag.), one of the most abundant and the most widely spread dominant of mixed prairie, was also grown. It was necessary to begin the experiment in a uniform soil and one free of underground plant parts. It seemed desirable to confine the roots to a definite volume of soil but one adequate for full underground development. Prevention of the roots of other plants from intermingling and competing with those of the grasses was also necessary. For these reasons the experimental grasses were grown in large steel drums. Seed of each grass was planted in the greenhouse on April 23, 1943, in 18 five-inch flower pots. The plants grew rapidly, and on May 22 the entire contents of the pots were placed in soil in the tops of the drums out-of-doors.

Nine steel drums, each 34 inches high, 22.5 inches in diameter, and of about 58 gallons capacity, were placed in a trench in a bluegrass lawn. They were in two rows. Holes 14 inches in depth and 5 inches in diameter were dug in the bottom of the trench and filled with coarse gravel.
In addition a layer of gravel several inches deep was placed in the bottom of the trench to insure good drainage. The bottoms of the drums were perforated from the outside by means of a hand pick which made holes approximately 6 by 8 millimeters in diameter. These were spaced about 2 inches apart. The perforations were covered from within with galvanized wire of coarse mesh upon which gravel was placed to a depth of one inch. The drums were then filled with good quality, silt-loam potting soil which had been screened, brought to an optimum water content for good growth, and thoroughly mixed. An exception was the soil in the three drums in which blue grama was planted. It had one-third river sand intermixed with it. In filling the drums the soil was tamped firmly in place. Soil was also packed around the drums until the trench was filled. Thus, the tops of the drums were about 2 inches above the general soil level, but soil was banked up about them.

Just before transplanting, the seedlings in each pot were thinned to 10 , except that 20 were left in those containing blue grama. Five pots of seedlings were transplanted into each drum. The plants were properly watered and mulched and all flourished (fig. 1). During periods of drought when the soil became dry to a depth of a foot or more, each lot was given an equal amount of water which was enough to promote good growth. At no time did the plants show wilting. Conversely, during periods of excessive rainfall, an improvised roof was placed over the plants at night or during heavy rains during the day. The soil was sampled to the bottom of the drums when it seemed advisable, but at no time did water content exceed field capacity. Growth each season was vigorous and continuous. After the grasses had completed vegetative growth and had flowered abundantly (about September 1 of each year) they were cut at the soil surface, and the tops were air-dried and weighed.

Three of the drums, each containing a 

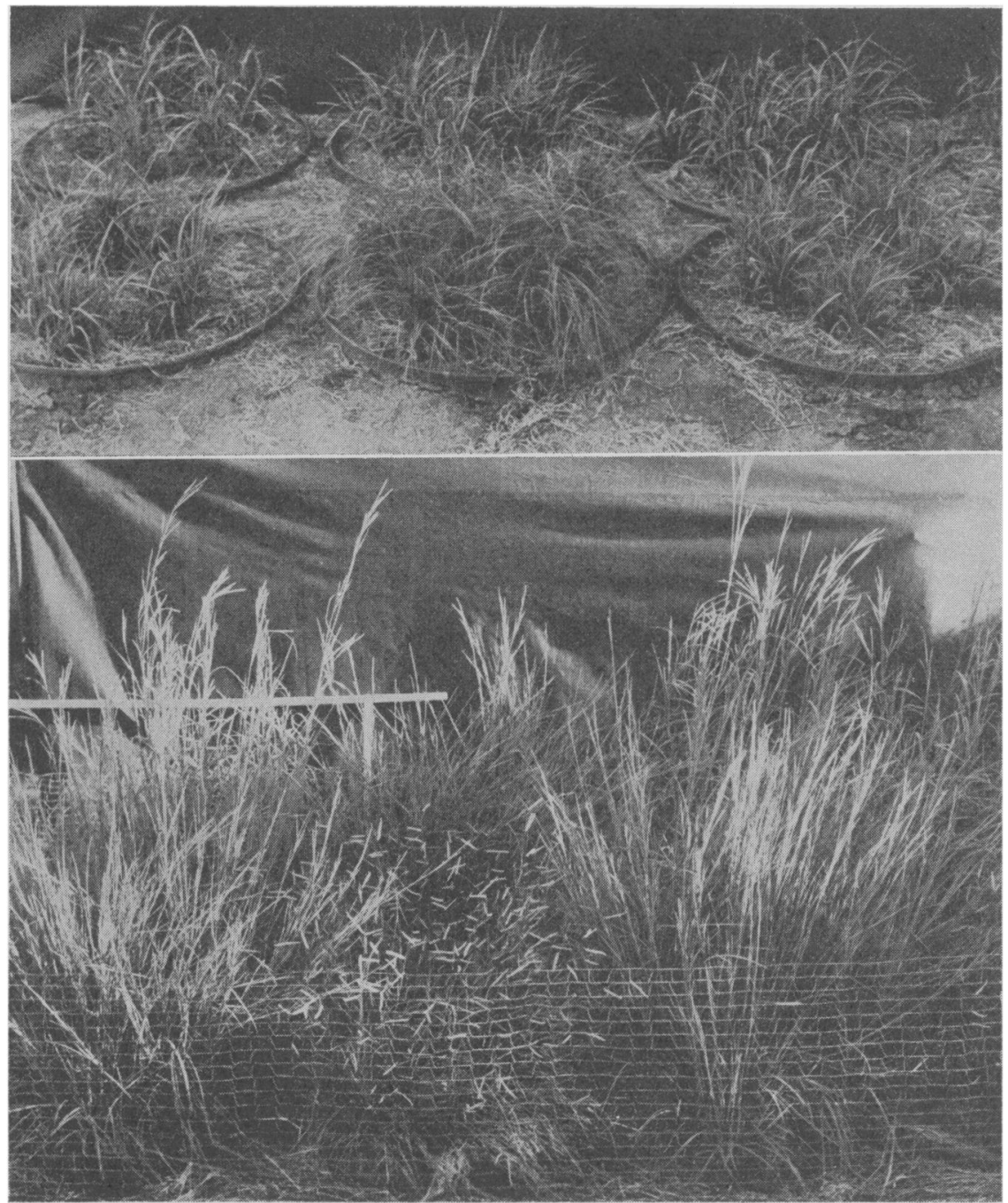

FIG. 1. (Upper) Six of the nine steel drums with seedlings on June 27, 1943 . (Lower) Same view on September 6, at the end of the first growing season. Blue grama occupies the center of the front row, with little bluestem on each side; big bluestem is growing at both ends of the back row.

different species, were removed to the greenhouse for examination of the roots at the end of each summer. Also, all of the remaining drums were tilted, and careful examination was made each year for any roots that might have grown through the openings in the bottoms. None was found. Each of the three drums was placed on its side in a long, deep tank filled with water, for a period of 48 hours. It was rotated from time to time, so that the whole soil mass was thoroughly soaked. Several sections of the bottom of the drum were then cut away with chisel and hammer. The upper end of the tank was then raised so as to incline the drum, and a stream of water from an open hose was applied to the top and upper inside portion of the drum until, after an hour or two, much soil was 
removed without damage to the roots. Water and soil leaving the tank during this process passed through a screen with 8 meshes per inch. One observer watched closely for roots or root fragments left on the screen. Few or none were found.

After long-continued washing the drum was finally turned so that the diminish-

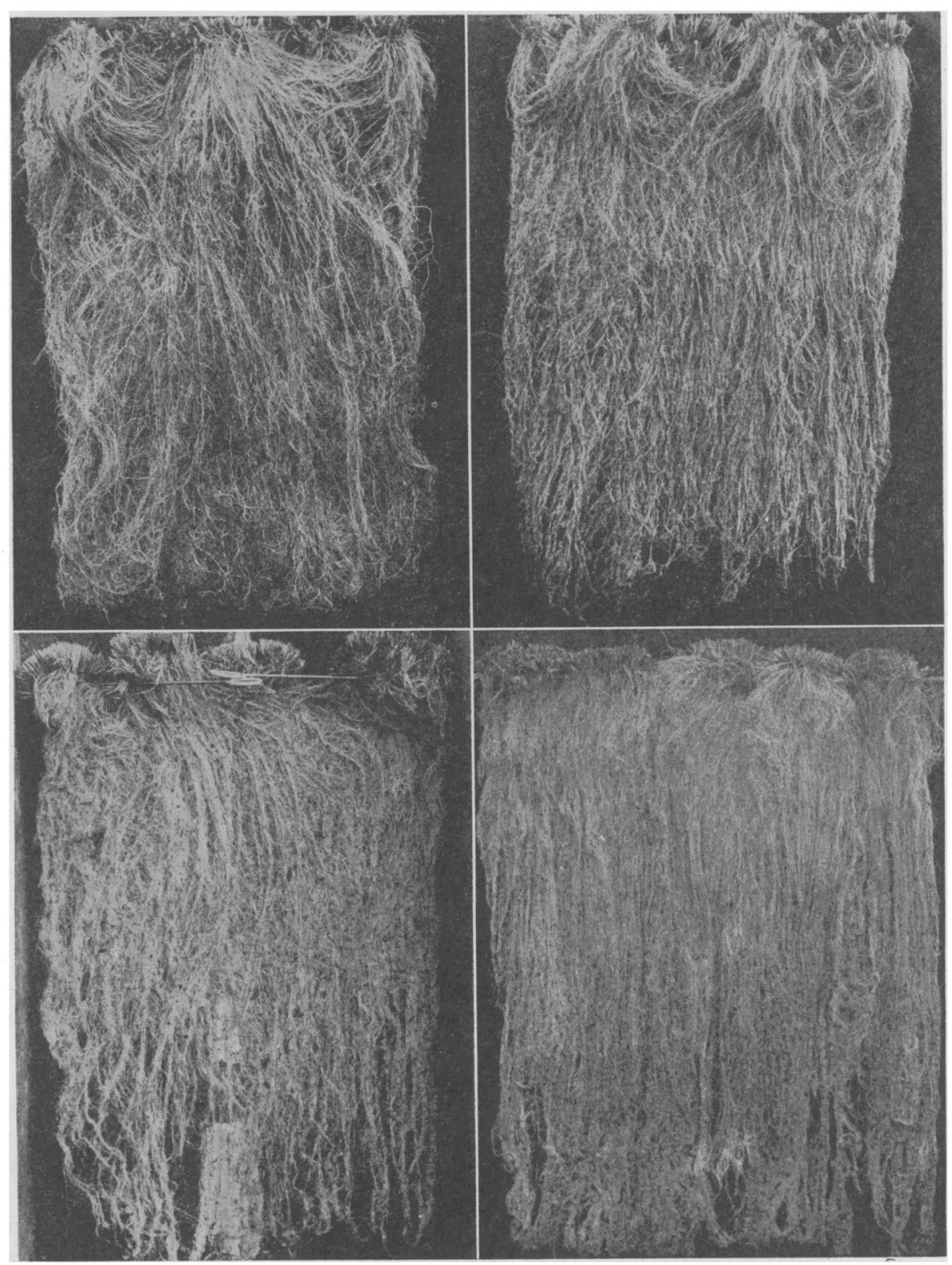

FIG. 2. (Upper) Root systems of Andropogon furcatus (left) and $A$. scoparius (right) on September 3 of the first growing season. Length is about 32 inches and dry weight of roots 152 and 89 grams, respectively. (Lower) Root systems of Bouteloua gracilis (left) on September 5 of the first growing season. Root depth is about 32 inches and dry weight 76 grams. Blue grama at the end of the second summer (right). Dry weight had increased 56 per cent. 
ing core of soil and roots was free on all sides. By this time it had decreased to about one-fifth of its original size. The drum was then tilted upward from the bottom and carefully pulled backward, leaving the soil-root mass in the inclined tank. The roots were then washed nearly free from soil and photographed. Even at the end of the first growing season, many roots in each drum extended to the bottom (fig. 2). The root systems were then cut into sections as follows: at a depth of 4 inches from the average place of attachment to the stems; at 12 inches depth; and at 24 inches. Thus, the fourth and deepest sample (below 24 inches) contained roots of about 8 inches or less in length. After further washing, the roots in the first section were severed at their point of attachment to the stems. Each section of roots was washed repeatedly in very large shallow pans, and the soil and water were drained off through the screen. The mass of roots was then separated and again washed in shallow, white, porcelain trays until the water remained clear and no particles of soil could be seen. There was some loss of the finest roots and of root hairs in the washing process, but the amount by weight was almost negligible, probably a small fraction of 1 per cent. The roots were dried for several days in a drying room with a temperature of $90^{\circ} \mathrm{F}$. and then weighed.

\section{Total Growth of Tops AND Roots}

Development of tops during each of the three years and total dry weight of roots are shown in table I. There was close agreement within the three lots of each species in all measurements of the tops in 1943. Average height of foliage and of flower stalks was approximately the same the next season. Average dry weight of tops of big bluestem increased 69 per cent the second year, and weight of roots 72 per cent (fig. 3). In little bluestem weight of tops exactly doubled, and rootweight increased 86 per cent. In blue grama the increase in weight of tops was 57 per cent; that of roots was 56 . As regards height, flowering, and root extent, the first season's growth was similar to that of plants of each species grown in fertile, field soil at Lincoln, Nebraska, in 1920 (Clements and Weaver, '24).

In 1945, the tops of all grasses were several inches taller and increase in dry weight continued. Tops of big bluestem were 48 per cent heavier and the root growth showed an increase of 23 per cent over that of the preceding year. Little bluestem made a 19 per cent gain in growth of tops, but lost 3 per cent in rootweight (table II and fig. 4). Weight of tops was 1 per cent greater than the preceding year in blue grama, but the rootweight was 22 per cent less. This means, of course, that the yield of tops of the 5

TABLE I. Average height of foliage and flower stalks, and dry weight of tops and roots of each lot of three species of grasses at the end of each of three growing seasons

\begin{tabular}{|c|c|c|c|c|c|c|c|c|c|c|c|c|}
\hline \multirow{2}{*}{ Species } & \multicolumn{3}{|c|}{$\begin{array}{c}\text { Av. height } \\
\text { foliage, inches }\end{array}$} & \multicolumn{3}{|c|}{$\begin{array}{l}\text { Av. height } \\
\text { flr. stalks, inches }\end{array}$} & \multicolumn{3}{|c|}{$\begin{array}{l}\text { Dry weight } \\
\text { tops, grams }\end{array}$} & \multicolumn{3}{|c|}{$\begin{array}{c}\text { Dry weight } \\
\text { roots, grams }\end{array}$} \\
\hline & '43 & '44 & '45 & '43 & '44 & 45 & '43 & '44 & '45 & '43 & ' 44 & 45 \\
\hline $\begin{array}{l}\text { Andropogon } \\
\text { furcatus }\end{array}$ & $\begin{array}{l}25 \\
26 \\
26\end{array}$ & $\begin{array}{l}28 \\
28\end{array}$ & 40 & $\begin{array}{l}45 \\
44 \\
43\end{array}$ & $\begin{array}{l}45 \\
43\end{array}$ & 54 & $\begin{array}{l}322 \\
331 \\
306\end{array}$ & $\begin{array}{l}565 \\
518\end{array}$ & 804 & 152.2 & 261.5 & 320.7 \\
\hline $\begin{array}{c}\text { Andropogon } \\
\text { scoparius }\end{array}$ & $\begin{array}{l}22 \\
24 \\
23\end{array}$ & $\begin{array}{l}22 \\
22\end{array}$ & 37 & $\begin{array}{l}36 \\
38 \\
36\end{array}$ & $\begin{array}{l}38 \\
40\end{array}$ & 47 & $\begin{array}{l}365 \\
394 \\
388\end{array}$ & $\begin{array}{l}735 \\
790\end{array}$ & 906 & 88.9 & 165.6 & 159.8 \\
\hline $\begin{array}{c}\text { Bouteloua } \\
\text { gracilis }\end{array}$ & $\begin{array}{l}16 \\
18 \\
17\end{array}$ & $\begin{array}{l}20 \\
20\end{array}$ & 24 & $\begin{array}{l}22 \\
23 \\
22\end{array}$ & $\begin{array}{l}22 \\
22\end{array}$ & 30 & $\begin{array}{l}259 \\
288 \\
283\end{array}$ & $\begin{array}{l}475 \\
394\end{array}$ & 441 & 75.7 & 118.3 & 92.4 \\
\hline
\end{tabular}




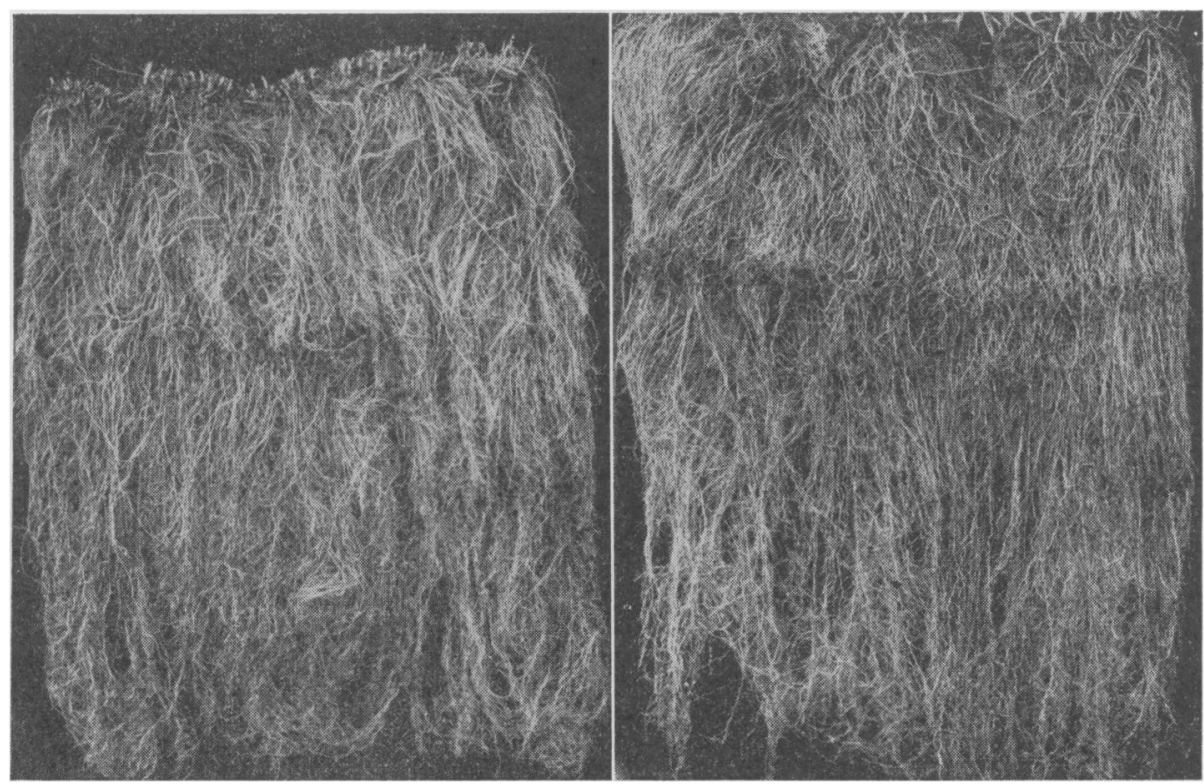

FIG. 3. Root systems of big bluestem at the end of the second summer (left) and third summer (right). Dry weight was 72 per cent greater the second year than the first (fig. 2), and an additional gain of 23 per cent was made the third year.

groups of plants of each species harvested in the drums in 1945 was greater than the average harvest of tops of these species, respectively, in 1944 . It should be noted that while both tops and roots of big bluestem increased in weight, the tops only of little bluestem gained in weight while the root-weight declined. In blue grama weight of tops increased slightly, but weight of roots decreased the third year. In a previous study ('46) the writers have shown that the root system of big bluestem, at least the roots produced before June 15 of the first year, remained alive longest. After 3 seasons of growth only 19 per cent had died, in contrast with 55 per cent in blue grama, and 90 per cent of those of little bluestem. It is of interest that little bluestem produced more top in proportion to roots each year then did big bluestem. Production of both tops and roots was least in the short grass.

An examination of table II reveals that the total increase in growth of tops of big bluestem and little bluestem was very similar, 151 and 137 per cent, respectively. While increase in weight of roots was less, yet it was high in both grasses, 111 and 80 per cent. Increase in growth of both tops and roots was more regular in

TABLE II. Percentage increase in dry weight of tops and roots (parentheses) each year over the preceding year, and total increase during three seasons' growth. Also the ratio of roots to tops

\begin{tabular}{|c|c|c|c|c|c|c|c|c|c|}
\hline \multirow{2}{*}{ Species } & \multicolumn{6}{|c|}{ Percentage increase } & \multicolumn{3}{|c|}{$\begin{array}{l}\text { Ratio of roots } \\
\text { to tops }\end{array}$} \\
\hline & \multicolumn{2}{|c|}{1944} & \multicolumn{2}{|c|}{1945} & \multicolumn{2}{|c|}{1943 to 1945} & 1943 & 1944 & 1945 \\
\hline $\begin{array}{l}\text { Andropogon furcatus } \\
\text { Andropogon scoparius } \\
\text { Bouteloua gracilis }\end{array}$ & $\begin{array}{r}69 \\
100 \\
57\end{array}$ & $\begin{array}{l}(72) \\
(86) \\
(56)\end{array}$ & $\begin{array}{r}48 \\
19 \\
1\end{array}$ & $\begin{array}{r}(23) \\
(-3) \\
(-22)\end{array}$ & $\begin{array}{r}151 \\
137 \\
59\end{array}$ & $\begin{array}{r}(111) \\
(80) \\
(22)\end{array}$ & $\begin{array}{l}.47 \\
.24 \\
.29\end{array}$ & $\begin{array}{l}.46 \\
.23 \\
.25\end{array}$ & $\begin{array}{l}.40 \\
.18 \\
.21\end{array}$ \\
\hline
\end{tabular}




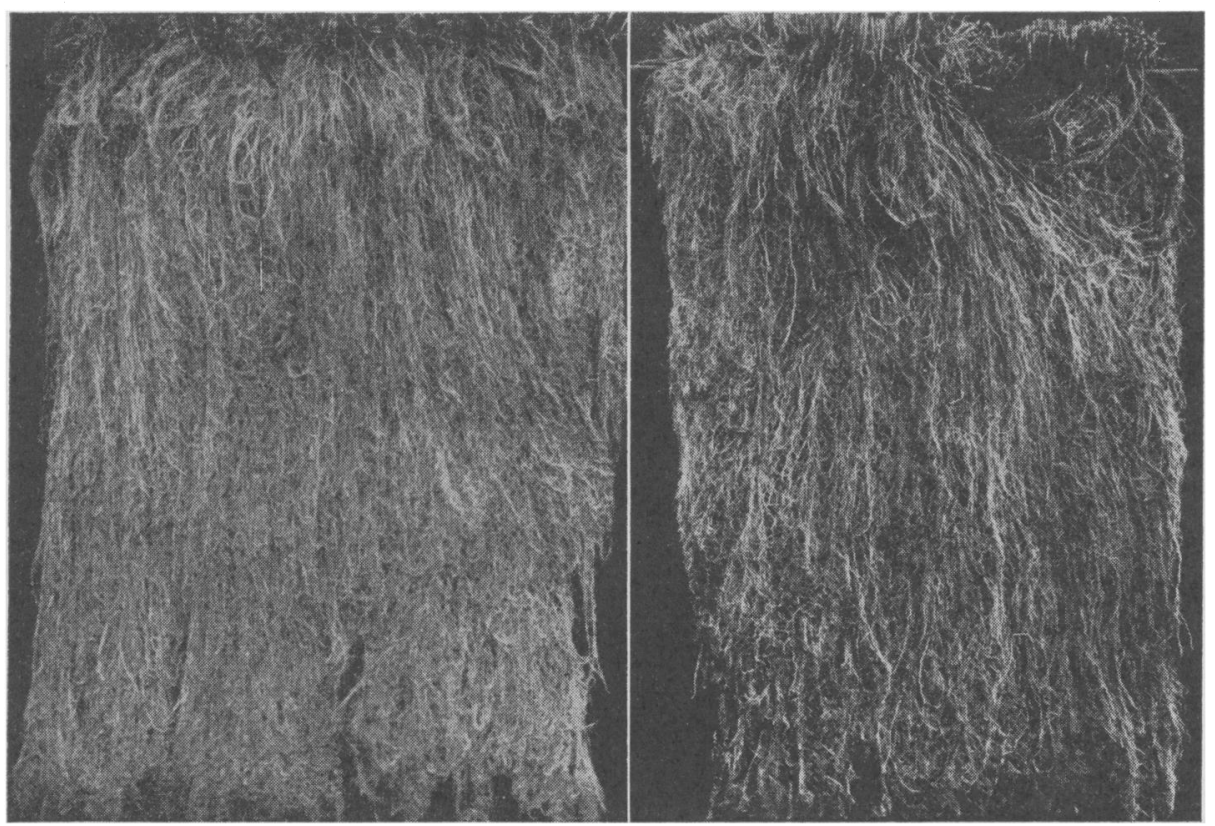

FIG. 4. Root systems of little bluestem at the end of the second summer (left) and third summer (right). Increase in root weight was 86 per cent over that of the first summer (fig. 2 ), but no additional gain was made the third year.

big bluestem; in little bluestem growth seemed to be completed as regards roots at the end of the second year. This was true also of blue grama, both roots and tops reaching maximum production the second growing season.

\section{Ratio of Roots to Tops}

The ratio of roots to tops was highest in big bluestem where the roots are very coarse, often 2 millimeters in diameter (table II). It was intermediate, however, in blue grama, which has much finer roots than little bluestem. There was a slight but consistent decrease in the roottop ratio of each species each year. This was most pronounced in blue grama.

\section{Amount and Increase of Roots at DiffERENT LEVELS}

An examination of the weight of roots produced at each depth shows (with slight exceptions) a decrease with depth (table III). This occurred in every lot of each species each year. The exceptions oc- curred in 1943, where both bluestems yielded slightly less in the first 4 inches than they did in the next 8 inches. In little bluestem 36 per cent of the entire root system by weight was found in the surface 4 inches after three growing seasons. In big bluestem it was 43 per cent, and in blue grama 49 . The first foot of soil contained 69 per cent of the roots of little bluestem, 78 of big bluestem, and 80 per cent of the roots of blue grama.

The greatest percentage increase in weight (136) was made by big bluestem in the surface 4 inches the second year. Increases at greater depths to 24 inches were about 33 per cent (table IV). This species continued to make large increases at this level ( 53 and 40 per cent) but very little elsewhere during the third year. Growth rate was high in little bluestem throughout the surface foot the second year (123 and 107 per cent increase), but slight or no increase occurred at this level the third summer. Also the considerable growth in the deeper soil (65 
TABLE III. Dry weight of roots in grams at the several depths at the end of each growing season, and the per cent of the entire root system at each depth after three seasons of growth

\begin{tabular}{|c|c|c|c|c|c|c|c|c|c|c|c|c|}
\hline \multirow{2}{*}{$\begin{array}{l}\text { Depth, } \\
\text { inches }\end{array}$} & 1943 & 1944 & 1945 & $\begin{array}{c}\text { Per } \\
\text { cent }\end{array}$ & 1943 & 1944 & 1945 & $\begin{array}{c}\text { Per } \\
\text { cent }\end{array}$ & 1943 & 1944 & 1945 & $\begin{array}{c}\text { Per } \\
\text { cent }\end{array}$ \\
\hline & \multicolumn{4}{|c|}{ Andropogon furcatus } & \multicolumn{4}{|c|}{ Andropogon scoparius } & \multicolumn{4}{|c|}{ Bouteloua gracilis } \\
\hline $0-4$ & 56.2 & 132.4 & 136.2 & 42.5 & 25.3 & 56.5 & 57.3 & 35.9 & 43.4 & 49.6 & 45.1 & 48.8 \\
\hline $4-12$ & 56.6 & 74.6 & 114.0 & 35.5 & 26.7 & 55.3 & 53.1 & 33.3 & 19.0 & 36.5 & 28.8 & 31.2 \\
\hline $12-24$ & 30.7 & 40.7 & 56.8 & 17.7 & 18.7 & 30.9 & 34.6 & 21.6 & 10.0 & 15.9 & 15.0 & 16.2 \\
\hline $24+$ & 8.7 & 13.8 & 13.7 & 4.3 & 18.2 & 22.9 & 14.8 & 9.2 & 3.3 & 16.3 & 3.5 & 3.8 \\
\hline
\end{tabular}

TABLE IV. Percentage increase in dry weight of roots at each level the second and third year over the preceding year, and total increase at the end of the third growing season over that of the first

\begin{tabular}{|c|c|c|c|c|c|c|c|c|c|}
\hline \multirow{2}{*}{$\begin{array}{l}\text { Depth, } \\
\text { inches }\end{array}$} & $\begin{array}{l}\text { Per cent } \\
\text { 2d year }\end{array}$ & $\begin{array}{l}\text { Per cent } \\
\text { 3d year }\end{array}$ & Total & $\begin{array}{l}\text { Per cent } \\
\text { 2d year }\end{array}$ & $\begin{array}{l}\text { Per cent } \\
\text { 3d year }\end{array}$ & Total & $\begin{array}{l}\text { Per cent } \\
2 \mathrm{~d} \text { year }\end{array}$ & $\begin{array}{l}\text { Per cent } \\
\text { 3d year }\end{array}$ & Total \\
\hline & \multicolumn{3}{|c|}{ Andropogon furcatus } & \multicolumn{3}{|c|}{ Andropogon scoparius } & \multicolumn{3}{|c|}{ Bouteloua gracilis } \\
\hline $\begin{array}{c}0-4 \\
4-12 \\
12-24 \\
24+\end{array}$ & $\begin{array}{r}136 \\
32 \\
33 \\
57\end{array}$ & $\begin{array}{r}3 \\
53 \\
40 \\
1\end{array}$ & $\begin{array}{r}142 \\
101 \\
85 \\
57\end{array}$ & $\begin{array}{r}123 \\
107 \\
65 \\
25\end{array}$ & $\begin{array}{r}1 \\
-4 \\
12 \\
-35\end{array}$ & $\begin{array}{r}127 \\
99 \\
85 \\
-18\end{array}$ & $\begin{array}{r}14 \\
92 \\
59 \\
394\end{array}$ & $\begin{array}{r}-11 \\
-21 \\
-6 \\
-77\end{array}$ & $\begin{array}{r}4 \\
52 \\
50 \\
6\end{array}$ \\
\hline
\end{tabular}

and 25 per cent) in 1944 continued much diminished into 1945 only in the second foot. In blue grama an increase of only 14 per cent occurred in the surface 4 inches the second year, but 92 and 59 at deeper levels. It seems that maximum weight was attained throughout, since dry weight showed decreases at all depths in 1945. Percentage of total growth (1943 to 1945) was greatest at all levels in big bluestem, slightly less in little bluestem, and very much less in blue grama. In the bluestems it decreased with depth. It was very small ( 4 to 6 per cent) in both the shallowest and deepest levels in blue grama and quite uniform (52 and 50 per cent) at 4 to 24 inches depth.

\section{Comparison of Roots in Containers ANd IN Prairie}

A comparison of the amount of roots in the drums after three summers' growth with those in an equal surface area of virgin prairie is pertinent. Studies on the relation of root distribution to organic matter in prairie soil (Weaver, Hougen, and Weldon, '35) record the amount of roots of big bluestem in a typical stand on lowland and those of little bluestem in its upland climax. Roots of blue grama were also secured later at the several soil levels under a typical old stand in a pasture. These data were obtained in eastern Nebraska for a surface area of one square meter. The field samples included the rhizomes and stem bases which occur underground. These were retained in the present experiment and were dried and weighed separately (fig. 5). The amounts, which were 542 grams per square meter for big bluestem, 572 for little bluestem, and 456 grams for blue grama, are added to the weights of the samples of roots in the surface foot in table $\mathrm{V}$.

An examination of table $\mathrm{V}$ shows that distribution of plant materials at the different depths is very similar to that in the natural environment. In amount, that of big bluestem in the containers somewhat exceeded that in prairie. The amount of underground materials of little bluestem was nearly the same under the two conditions of growth. But the 

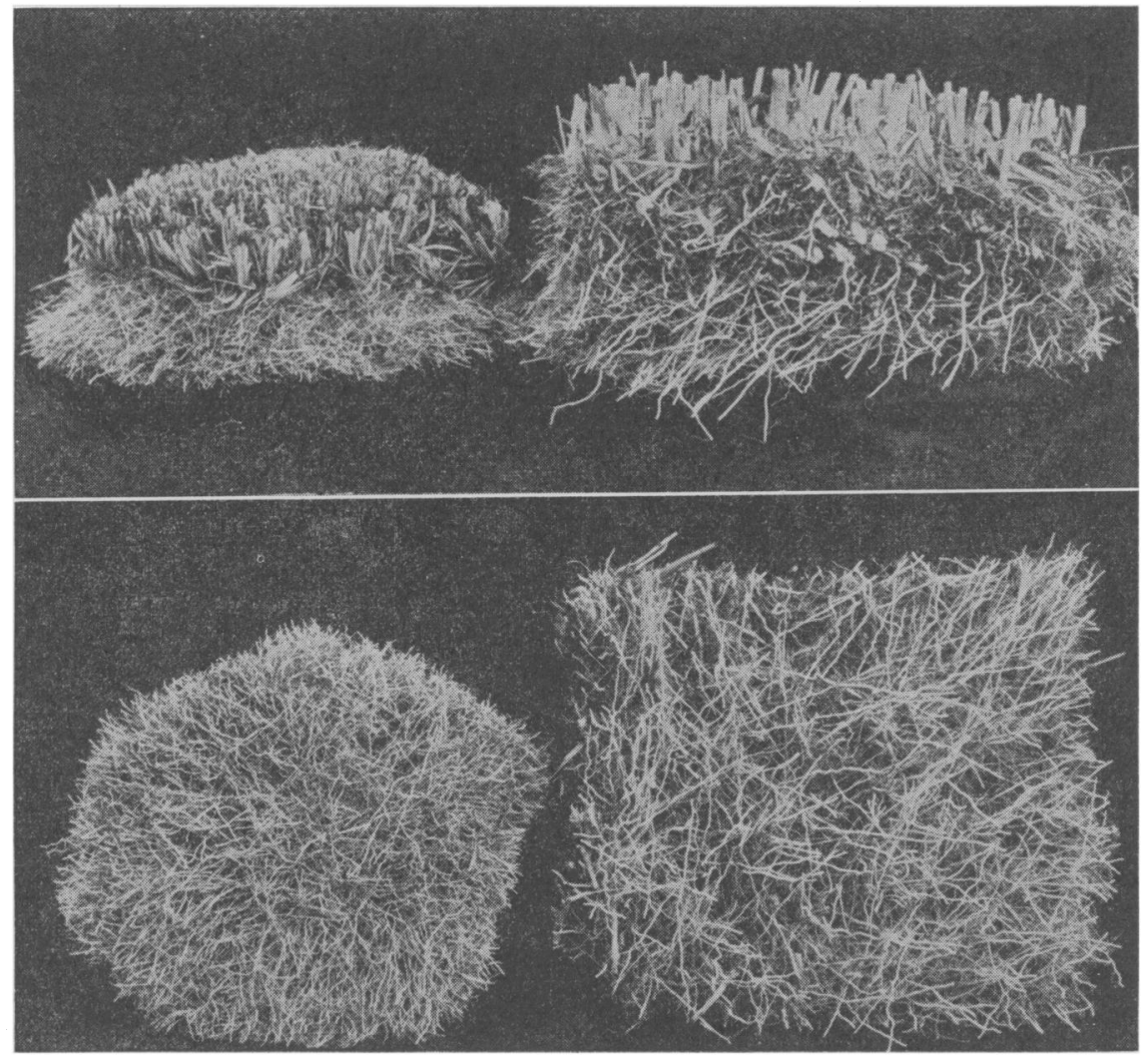

FIG. 5. (Upper) Portions of stems, stem-bases, and rhizomes which occurred underground on a three-year-old bunch of little bluestem (left) and big bluestem (right). (Lower) Same crowns inverted showing the large numbers and different size of roots in the two species of bluestems.

amount in blue grama considerably exceeded that in the pasture, where the grass had been grazed.

TABLE V. Comparison of amounts of underground plant material produced in the containers at the several depths with that produced in virgin prairie. All data are presented on the basis of grams per square meter

\begin{tabular}{l|r|r|r|r|r|r}
\hline \hline $\begin{array}{c}\text { Depth } \\
\text { of } \\
\text { sample, } \\
\text { inches }\end{array}$ & \multicolumn{2}{|c|}{$\begin{array}{c}\text { Andropogon } \\
\text { furcatus }\end{array}$} & \multicolumn{2}{|c|}{$\begin{array}{c}\text { Andropogon } \\
\text { scoparius }\end{array}$} & \multicolumn{2}{|c}{$\begin{array}{c}\text { Bouteloun } \\
\text { gracilis }\end{array}$} \\
\cline { 2 - 6 } & $\begin{array}{c}\text { Con- } \\
\text { tainers }\end{array}$ & Prairie & $\begin{array}{c}\text { Con- } \\
\text { tainers }\end{array}$ & Prairie & $\begin{array}{c}\text { Con- } \\
\text { tainers }\end{array}$ & Prairie \\
\hline $0-12$ & 1,517 & 1,186 & 1,002 & 939 & 745 & 528 \\
$12-24$ & 222 & 179 & 135 & 193 & 59 & 27 \\
$24+$ & 53 & 140 & 58 & 98 & 14 & 7 \\
\hline Total & 1,792 & 1,505 & 1,195 & 1,230 & 818 & 562 \\
\hline
\end{tabular}

From these data, as well as from the small or negative percentages of increase in weight during the third summer (table IV), it may be concluded that big bluestem reached approximately its maximum root weight by the end of the third summer and little bluestem and blue grama a year earlier. Further evidence for this conclusion is had from a comparison with previous extensive sampling of these grasses.

The amounts of underground plant material to a depth of 12 inches in virgin prairie were obtained near Lincoln, Nebraska, for various range grasses by Weaver and Harmon ('35). A wider study at many stations in western Iowa and eastern Nebraska was then made by 
TABLE VI. Comparison of amounts of underground materials produced in the containers with porduction in prairie. All data are presented on the basis of grams per square meter

\begin{tabular}{|c|c|c|c|c|c|c|c|c|c|}
\hline \multirow{2}{*}{$\begin{array}{l}\text { Depth of } \\
\text { sample, } \\
\text { inches }\end{array}$} & \multicolumn{3}{|c|}{ Andropogon furcatus } & \multicolumn{3}{|c|}{ Andropogon scoparius } & \multicolumn{3}{|c|}{ Bouteloua gracilis } \\
\hline & Containers & Prairie $^{1}$ & Prairie $^{2}$ & Containers & Prairie $^{1}$ & Prairie $^{2}$ & Containers & Prairie $^{1}$ & Prairie $^{2}$ \\
\hline $\begin{array}{l}0-4 \\
4-12\end{array}$ & $\begin{array}{r}1,073 \\
445\end{array}$ & 794 & $\begin{array}{l}924 \\
302\end{array}$ & $\begin{array}{l}795 \\
207\end{array}$ & 582 & $\begin{array}{l}752 \\
250\end{array}$ & $\begin{array}{l}632 \\
112\end{array}$ & 512 & $\begin{array}{l}546 \\
202\end{array}$ \\
\hline Total & 1,518 & & 1,226 & 1,002 & & 1,002 & 744 & & 748 \\
\hline
\end{tabular}

${ }^{1}$ Data from Shively and Weaver, 1939. Averages of 9, 8, and 5 half-square-meter samples per species in the order given in the table.

2 Data from Weaver and Harmon, 1935. Averages of 6, 6, and 4 half-square-meter samples per species in the order given in the table.

Shively and Weaver ('39), but only to a depth of 4 inches (table VI). The data from the 4-inch level show again that the weight of big bluestem in the drums somewhat exceeded that in prairie. The amounts of little bluestem and blue grama were also slightly higher than in the natural environment. At the deeper level, weight of roots was usually smaller in the drums. Total weight of roots of big bluestem per unit area in the experiment was somewhat larger than in prairie, but the weight was equal in amount to that in prairie for both little bluestem and blue grama.

\section{Discussion}

The importance of the depth and extent of roots of grasses in producing crops of hay or abundant forage under continuous grazing or even during drought is well known. To this knowledge must now be added the effect of roots on the structure and organic matter content of the soil. In other words, a stand of grass plays a dual role. Much emphasis has been placed upon the quantity and quality of forage produced, since it is immediate and obvious. Perhaps an equally great and certainly a more permanent value is obtained from the crop of underground parts in their effects upon the soil.

The root-top ratios presented earlier are somewhat misleading since the roots alone of the underground parts were considered. If we add to these the consider- able amounts of organic materials afforded by the root-crown, which includes rhizomes as well as stem-bases, the root-stem ratio in big bluestem becomes, after three seasons of growth, 0.57. Likewise the ratios in little bluestem and blue grama increase to 0.34 and 0.47 respectively. Shively and Weaver ('39) ascertained that in upland climax prairie dominated by little bluestem, where the yield of hay was about 1-1.5 tons annually, there were 2.6 tons of undecayed, underground plant materials in the surface 4 inches of soil. Similarly, in good stands of big bluestem where annual forage production reached 2 tons or more per acre there was still more than this amount of plant material (3.5 tons per acre) in the surface soil. The apparent discrepancy between these and the preceding data is due not to the smaller amount of underground parts in the experimental material but to the greatly increased production of the tops of this well-lighted and vigorous new growth. The greater vigor and increased stature of bluestem grasses was also observed in prairie which previously had been subjected to injury by drought. During recovery, height of foliage in the bluestem was often increased 10 to 12 inches and production of unusually large and numerous flower stalks occurred. Moreover, the foliage per plant was much denser than in the adjacent, sod-bound prairie which had escaped partial thinning by drought (Weaver and Albertson, '44). 
The roots alone produced in this experiment amounted to approximately 5.5 tons per acre in big bluestem, 2.7 in little bluestem, and 1.6 tons in blue grama. These amounts might be expected after three years from full stands of similar grasses cut annually for hay. If they were pastured the quantity would be somewhat to considerably decreased, since repeated removal of part of the tops is very detrimental to root production. In the surface 12 inches alone the amounts are, in the same order, approximately $8,705,3,841$ and 2,571 pounds per acre. The yield of big bluestem is greater but the other grasses yielded less than did 3year-old crested wheat grass (Agropyron cristatum (L.) Beauv.) and brome grass (Bromus inermis Leyss), as ascertained by Stevenson and White ('41) at Saskatoon, Canada. Their findings were 5,244 and 4,657 pounds per acre-foot, respecively; the yield of roots of slender wheat grass (Agropyron pauciflorum (Schwein.) Hitchc.) was much lower. They found that crested wheat grass added each year to the root fiber present in the first foot of soil and that 5-year-old stands had built up over 3 tons of root fiber per acre in the surface foot. This was about one-half the quantity of root fiber present in the native prairie. Yields of root fiber of brome grass were very similar to those of crested wheat grass.

As regards the depth of greatest amounts of roots, Pavlychenko ('42) stated that in 4-year-old sods of crested wheat grass, brome grass, and slender wheat grass, more than half of the underground material was concentrated in the upper 6 inches of soil. Stevenson and White ('41) found 75 per cent of the roots of these three grasses in the upper 6 inches and 88 per cent in the surface foot, although the roots extended to a depth of about 5 feet. In the present study 43 and 36 per cent of the roots of big bluestem and little bluestem, respectively, and 49 per cent of those of blue grama, occurred in the surface 4 inches; while 78,69 , and 80 per cent of the root systems, respectively, occupied the surface foot.

It is generally conceded that the most efficient method in nature of producing a granular soil structure is the growing of a crop of perennial grass. Jacks ('44) stated that in all climates soil granulation becomes greater under perennial grasses than under any other kind of vegetation. This is a most important reason for introducing these grasses in the crop rotation. Simple addition of organic matter itself is not nearly so efficient a measure in the formation of a good structure. The quality as well as the quantity of root fiber is important. Both Stevenson and White ('41) and Pavlychenko ('42) concluded that slender wheat grass is of little or no value in improving soil structure. The annual grain crops produce large amounts of roots in the soil each year, but the fiber loses its strength immediately after harvest, and the roots undergo rapid decomposition. Why different soil structures occur under different species of grass is unknown, but it is common knowledge that such differences do occur. Under virgin stands of big bluestem in eastern Nebraska the soil is very coarsely granular. Samples collected at Lincoln contained approximately 21 per cent of water-stable aggregates 4 to 0.8 millimeters in diameter. Soil long covered with the finely rooted blue grama has a finer granulation quite similar to that under little bluestem. Thus, while the virgin soil under these grasses contained from 17 to 21 per cent of structural aggregates 4 to 0.8 millimeters in diameter, in an adjoining field where the prairie was broken and cropped for a decade only 0.5 per cent of these aggregates remained intact $^{2}$ (fig. 6).

In the arid lands in southern Saskatchewan, Pavlychenko ('42) found that the percentage of large aggregates ( 4 to $0.8 \mathrm{~mm}$. in diameter) in the surface 4 inches of soil was only 0.61 under continuous crops of wheat. Where crested

2 Soil samples collected by the senior author were analyzed by Dr. T. K. Pavlychenko. 


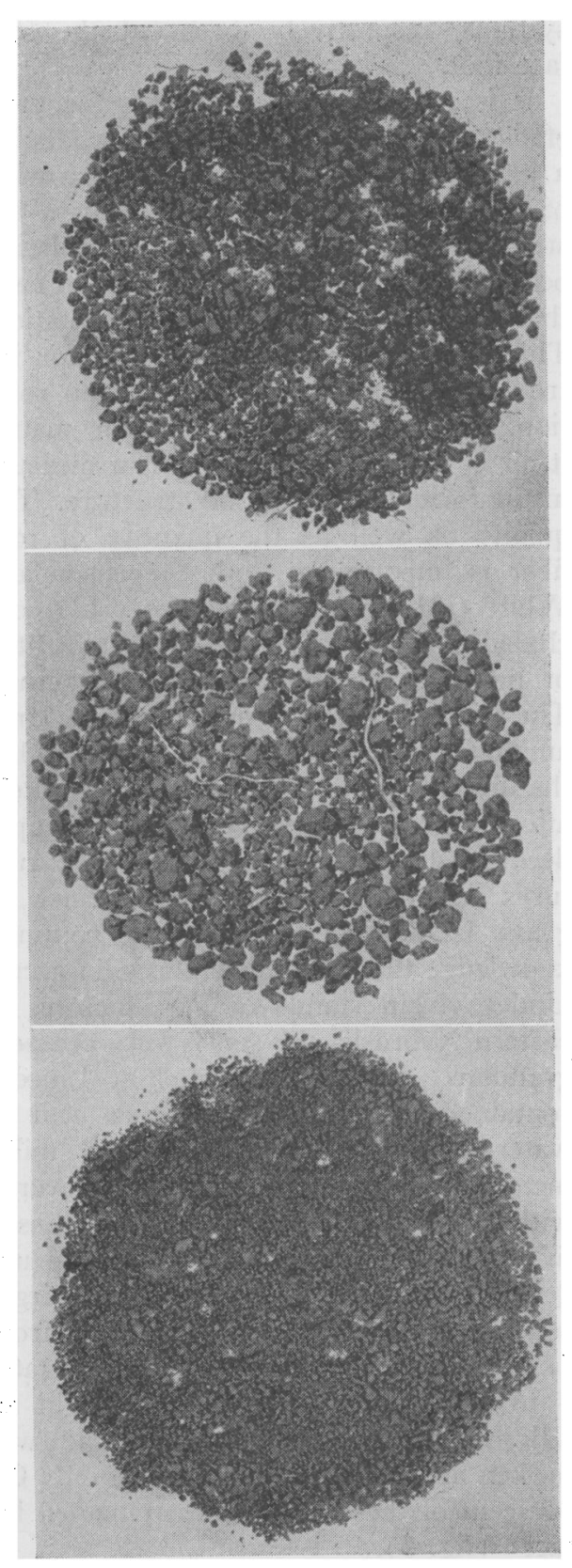

Fig. 6. Samples showing large soil granules in the surface 4 inches of virgin prairie; (Upper) under a very old stand of Bouteloua gracilis, and (Middle) under a similar stand. of Andropogon furcatus. The largest granules are about $4 \mathrm{~mm}$. in diameter. (Lower) The same soil after a decade of cropping to maize. Samples taken at Lincoln, Nebraska. wheat grass had been grown for five years in this soil there was 15.23 per cent of the coarse aggregates, and, as with brome grass, when the land was plowed the sod formed an almost unbroken furrow slice as does native prairie sod.

The time required for the completion of the structure-forming effect of a perennial grass crop probably varies considerably with climate and kind of soil. It was found to be 2 to 3 years by Rostovzeva and Avaeva ('35) working with various soils (but including chernozems) in the U. S. S. R. Pavlychenko ('42) found that crested wheat grass in a period of 5 years restored the surface 4 inches of soil, which had previously been in continuous grain for more than 20 years, to the condition found in virgin needle-grass prairie. This is in accord with the results of Guscin ('40), working in the dry climate of the southeastern part of the U. S. S. R., who ascertained that the amounts of root residues of crested wheat grass increased up to the fourth year of the stand, when an increase of about 13 per cent over the previous year was recorded. Stevenson and White ('41) concluded "that for the clay loam soils at Saskatoon 5-year-old stands of crested wheat grass will provide a satisfactory restoration of soil structure." In the present experiments the maximum amount of root materials was formed by blue grama and little bluestem after two growing seasons and after three by big bluestem. Jacks ('44), after considering the available literature concluded : "So far as one can generalize from ... experiments, it would appear that the full effect of a ley on soil structure is achieved in two years in moist, and in four years in dry, temperate regions, and that the structure so formed is destroyed by cultivation in about the same periods."

\section{SumMARY}

Separate lots of three range grasses were grown in large steel drums. At the end of each summer the root systems were washed free of soil and photographed, and the dry weights obtained. 
Roots of big bluestem produced 152 grams dry weight the first year, but this increased 72 per cent the second summer, and 23 per cent the third. During the second year increase in weight was greatest (136 per cent) in the first 4-inch level, but during the third year in the 4 12 and 12-24 inch depths (53 and 40 per cent).

Little bluestem produced 89 grams of roots the first year; the amount increased 86 per cent the second summer, after which the root weight slightly declined. Most rapid increase the second year was in the surface foot, and especially in the surface 4 inches (123 per cent).

Blue grama produced 76 grams of roots the first year, and reached its maximum development the second, increasing mostly (92 per cent) in the 4-12 inch depth, but also 59 per cent in the second foot.

Big bluestem reached approximately its maximum root development the third summer. Both little bluestem and blue grama attained maximum root development a year earlier.

The underground materials produced in 3 years were very similar in amounts to those ascertained earlier in typical mature stands in native prairie. They were also very nearly the same in the surface 4 inches and especially in the surface 12 inches as the average amounts ascertained by extensive sampling in climax prairie dominated by each species, respectively.

Roots alone yielded approximately 5.5 tons per acre after 3 years in big bluestem, 2.7 in little bluestem, and 1.6 tons in blue grama. Of these amounts 43,36 , and 49 per cent, respectively, occurred in the surface 4 inches, and 78,69, and 80 per cent in the first 12 inches.

The effects of roots of grass in producing a granular soil structure, the time required for the completion of the structure-forming effect, decrease or loss of soil granulation under continuous crop- ping to cereals, and the restoration of good structure and fertility by growing perennial grasses, are considered.

\section{Literature Cited}

Burton, G. W. 1943. A comparison of the first year's root production of seven southern grasses established from seed. Jour. Amer. Soc. Agron. 35: 192-196.

Clements, F. E., and J. E. Weaver. 1924. Experimental vegetation. Carnegie Inst. Wash. Publ. No. 355.

Guscin, I. V. 1940. Root remains of perennial plants under the conditions of the dry South-east. Herb. Abs. 12: Abs. 170.

Jacks, G. V. 1944. The influence of herbage rotations on the soil. In Alternate husbandry. Imperial Agric. Bur. Joint Pub. 6.

Newell, L. C. 1944. In Alternate husbandry; quoted by R. O. Whyte, p. 20. Imperial Agric. Bur. Joint Pub. 6.

Pavlychenko, T. 1942. Root systems of certain forage crops in relation to the management of agricultural soils. Nat. Res. Council of Canada and Dom. Dept. Agric. N. R. C. Pub. 1088.

Rostovzeva, O. S., and M. I. Avaeva. 1935. The role of perennial grasses in the formation of compact soil structure. (English summary) Pedology 5 and 6: 813814.

Shively, S. B., and J. E. Weaver. 1939. Amount of underground plant materials in different grassland climates. Univ. Nebr. Cons. and Surv. Div. Bull. 21.

Stevenson, T. M., and W. J. White. 1941. Root fiber production of some perennial grasses. Sci. Agric. 22: 108-118.

Weaver, J. E., and F. W. Albertson. 1944. Nature and degree of recovery of grassland from the great drought of 1933 to 1940. Ecological Monogr. 14: page 428.

Weaver, J. E., and G. W. Harmon. 1935. Quantity of living plant materials in prairie soils in relation to run-off and soil erosion. Univ. Nebr. Cons. and Surv. Div. Bull. 8.

Weaver, J. E., V. H. Hougen, and M. D. Weldon. 1935. Relation of root distribution to organic matter in prairie soil. Bot. Gaz. 96: 389-420.

Weaver, J. E., and E. Zink. 1946. Length of life of roots of ten species of perennial range and pasture grasses. Plant Physiol. In press. 